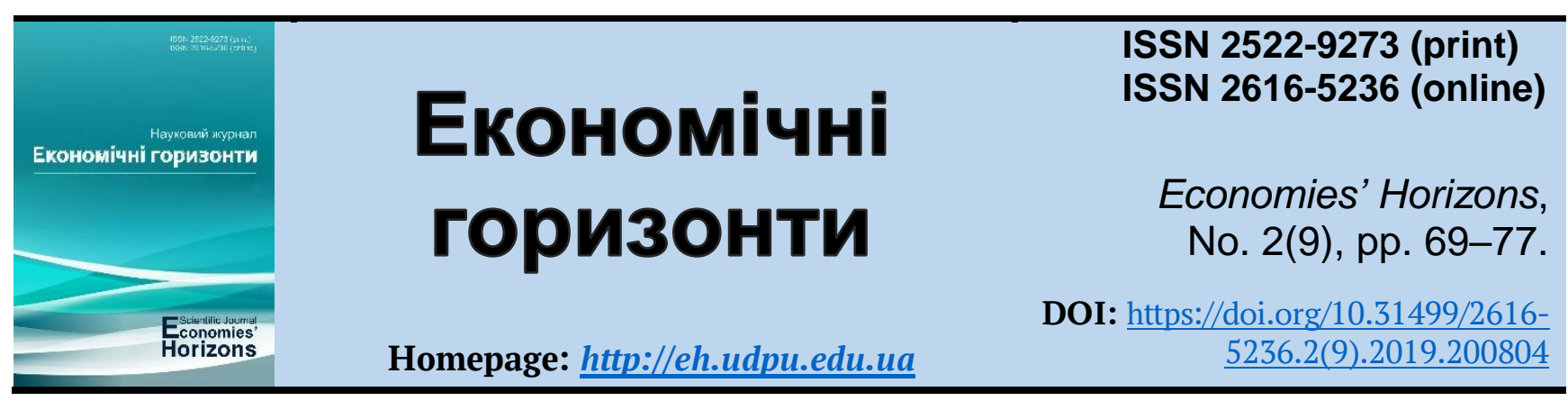

UDC 331.1

\title{
Features of modeling factors influencing the employment level of the population
}

\author{
Vitalii V. Burkun ${ }^{1}$, Cand. Ec. Sc. \\ Oleksandr S. Bulavchenko
}

Received: 30 April 2019 Accepted: 02 June 2019
Burkun, V. V. and Bulavchenko, O. S. (2019), "Features of modeling factors influencing the employment level of the population", Economies' Horizons, no. 2(9), pp. 69-77, doi: https://doi.org/10.31499/2616-5236.2(9).2019.200804.

Abstract. The purpose of the research. The purpose of the article is to determine the features of modeling factors influencing the employment level of the population. Methodology. The general scientific methods, including the generalization and comparison methods, are used to analyze the views of scientists on the methods of simulation modeling of various social and economic processes. Results. The features of simulation modeling processes that affect the employment of the population were analyzed in the article. Environmental factors influencing the employment level of the population were highlighted. On the basis of simulation modeling and calculation of relevant indices based on the correlationregression analysis of factors dependence and their influence on the employment of the population, the model contours were formed. The conducted modeling allows determining that the employment level of the population is significantly influenced by the indices of economic nature and educational and professional level. The disproportionality between supply and demand at a job market of the needs of educational and professional level among the employers and the job seekers was established. It was determined that it is expedient to solve the issues concerning the supply and demand disproportionality at a job market nationwide, on the basis of the development of measures for close cooperation between the state, higher education institutions and employers. Practical meaning. Analyses and deepening the understanding of the essence of simulation modeling of factors influencing the employment level of the population will allow to develop more effective organizational measures to overcome the negative phenomena in supply and demand disproportionality at the job market. It is determined that in order to apply simulation modeling of the processes of influence on the employment of population it is necessary to determine the causal relationships between the system indices; to conduct experiments with models at different values of the input parameters; selection of parameters for impact analysis; analysis of the sensitivity and strength of each factor impact on the resulting index; the ability to develop a system of interconnected models detailing the impact factors for individual indices of other models etc. Based on the analysis of methodological support of the employment process of the population, using the simulation modeling, it is advisable to determine the interrelation of factors influencing the employment

\footnotetext{
1 Orion-Avto Limited Liability Company; ORCID: https://orcid.org/0000-0002-4318-8483; e-mail: tanyastroyko@gmail.com.

2 Black Sea Research Institute of Economy and Innovation; Postgraduate Student; ORCID: https://orcid.org/0000-0003-4383-8252; e-mail: bulavchenko@gmail.com.
} 
process of the population through the interaction of universities and business, which will allow to develop the organizational support for state regulation of employment. Prospects for further research. The conducted modeling allows determining that the employment level of the population is significantly influenced by indices of economic nature and educational and professional level. The disproportionality between supply and demand at a job market of the needs of educational and professional level among the employers and the job seekers was established. It was determined that it is expedient to solve the issues concerning the supply and demand disproportionality at a job market nationwide, on the basis of the development of measures for close cooperation between the state, higher education institutions and employers, which needs further scientific and practical research and development.

Keywords: employment, modeling, factors, dependency, supply and demand.

JEL Classification: E24, F66, J21.

Number of references: 11; number of tables: 0; number of figures: $\mathbf{1}$; number of formulas: $\mathbf{1}$.

\title{
Особливості моделювання факторів впливу на рівень зайнятості населення
}

\author{
Віталій Валерійович Буркун ${ }^{1}$, к. е. н. \\ Олександр Семенович Булавченко ${ }^{2}$
}

Стаття надійшла: 30.04.2019 Стаття прийнята: 02.06.2019
Burkun V. V., Bulavchenko O. S. Features of modeling factors influencing the employment level of the population. Економічні горизонти. 2019. № 2(9). С. 6977. DOI: $10.31499 / 2616-5236.2(9) .2019 .200804$.

Анотація. Метою статті є визначення особливостей моделювання факторів впливу на рівень зайнятості населення. Методологія. У досліджені застосовані загальнонаукові методи, зокрема узагальнення, порівняння - для аналізу поглядів науковців щодо методики проведення імітаційного моделювання різних соціально-економічних процесів. Результати. В роботі було проаналізовано особливості імітаційного моделювання процесів які впливають на зайнятість населення. Було виокремлено фактори зовнішнього середовища, які мають вплив на рівень зайнятості населення. На основі імітаційного моделювання та розрахунку відповідних показників на основі кореляційно-регресійного аналізу залежності факторів та їх вплив на зайнятість населення було сформовано контури моделі. На основі проведеного моделювання було визначено, що на рівень зайнятості населення суттєвий вплив мають показники економічного характеру та освітньо-професійного рівня. Встановлено не відповідність попиту та пропозиції на ринку праці серед потреб освітньо-професійного рівня у роботодавців до пошукачів роботи. Визначено, що питання збалансування попиту та пропозиції на ринку праці доцільно вирішувати на державному рівні, на основі розробки заходів щодо тісної співпраці держави, закладів вищої освіти та роботодавців. Практичне значення. Аналіз та поглиблення розуміння сутності імітаційного моделювання факторів впливу на рівень зайнятості населення дозволить більш ефективно розробляти організаційні заходи щодо подолання негативних явищ у збалансуванні попиту та пропозиції на ринку праці. Визначено, що для застосування імітаційного моделювання процесів впливу на зайнятість населення необхідним $\epsilon$ визначення причинно-наслідкових зв'язків між показниками системи; проведення експериментів з моделями за різних значень вхідних параметрів; відбір параметрів для аналізу впливу; проведення аналізу чутливості та сили впливу кожного з факторів на результуючий показник; можливість побудови системи пов'язаних між собою моделей, що деталізують

Tовариство 3 обмеженою відповідальністю «Оріон-Авто»; ідентифікатор ORCID: https://orcid.org/0000-0002-4318-8483; e-mail: tanyastroyko@gmail.com.

${ }^{2}$ Причорноморський науково-дослідний інститут економіки та інновацій; здобувач; ідентифікатор ORCID: https://orcid.org/0000-0003-4383-8252; e-mail: bulavchenko@gmail.com. 
фактори впливу для окремих показників інших моделей тощо. На основі проведеного аналізу методичного забезпечення процесу зайнятості населення, за допомогою імітаційного моделювання доцільним $є$ визначення взаємозв'язку факторів впливу на процес працевлаштування населення за рахунок взаємодії закладів вищої освіти та бізнесу, що дасть змогу розробити організаційне забезпечення державного регулювання працевлаштування. Перспективи подальших досліджень. На основі проведеного моделювання було визначено, що на рівень зайнятості населення суттєвий вплив мають показники економічного характеру та освітньо-професійного рівня. Встановлено не відповідність попиту та пропозиції на ринку праці серед потреб освітньо-професійного рівня у роботодавців до пошукачів роботи. Визначено, що питання збалансування попиту та пропозиції на ринку праці доцільно вирішувати на державному рівні, на основі розробки заходів щодо тісної співпраці держави, закладів вищої освіти та роботодавців, що потребує подальших науково-практичних розробок.

Ключові слова: зайнятість, моделювання, фактори, залежність, попит та пропозиція.

Кількість джерел: 11; кількість таблиць: 0; кількість рисунків: 1; кількість формул: 1.

\section{Introduction.}

Simulation modeling is one of the research methods, where the studied is replaced by a model that describes the real system with sufficient accuracy, that allows, using the necessary information, to simulate the behavior of certain contours in part, taking into account the change of one or more of them. Simulation modeling is considered as a separate system of mathematical modeling. There is a class of objects for which for various reasons there is no development of analytical models or it is not possible to calculate the derived model. In such cases, the mathematical model is replaced by the simulation model. The use of simulation modeling of different processes has become widespread in modern conditions, however, issues related to the choice of factors that influence a particular process are not resolved, which makes the research relevant.

\section{Literature review.}

The scientific works of many scientists, such as: O. Dorokhov (2008), V. Heyets, T. Klebanova, O. Chernyak and M. Kyzym (2008), N. Kizim, V. Haustova, O. Polyakova and S. Omarov (2010), V. Bobilev (2012) and others are devoted to the issues of using the simulation modeling of different social and economic processes. However, the selection of factors influencing the social and economic processes, namely employment of the population, in this aspect requires more detailed study, since dynamic processes of time economic development change the force of influence of one or another factor.

\section{Methods.}

The general scientific methods, including the generalization and comparison methods, are used to analyze the views of scientists on the methods of simulation modeling of various social and economic processes.

\section{Research objectives.}

The purpose of this work is to determine the features of modeling factors influencing the employment level of the population.

\section{Results and discussions.}

The essence of simulation statistical modeling is to conduct simulation experiments with mathematical models, which in the process simulate the behavior of real objects, processes and systems in time and space over a given period. From the mathematical point of view, simulation modeling is a set of methods of algorithmic functioning of research objects, software implementation of algorithmic descriptions, functions of organization, planning and execution by electronic computing methods and experiments with mathematical models. One of the means of solving economic problems in the analytical research 
implementation is the use of economic and mathematical calculations. A simulation model is a simplified representation of a real object or phenomenon. The model itself can be a source of information about an object in terms of its study, analysis and improvement. In this case, the degree of similarity between the model and the object is significant, while the difference between them is insignificant. The peculiarity of the simulation method is that this method is not a method of mediate and not direct cognition, since the simulation model is a certain tool of cognition used in the study of a specific object (Kravets, 2010). Imitation modeling in modern conditions is an effective tool for the study of complex processes that take place in the field of social and labor relations and in the sphere of population employment in particular. Usually, when using simulation modeling, most authors mean the computer model, that is, a computer program that represents processes and phenomena that exist in the social and economic space. Simulation is a process of "executing" a model that causes the model to go through a sequence of state changes (discrete or continuous). Simulation models have "inputs" of information, that is, attributes and parameters that should match the model to real objects. The use of simulation modeling allows to understand the behavior of the system under the influence of various factors, to predict its change in the future ( $\mathrm{TO}^{-}$ mashevskyi, 2005).

Simulation has many advantages, the main ones are:

- high adequacy and accuracy between the economic essence of the described process and its model;

- the ability to describe complex systems at a high in-depth level of its elements and processes;

- much more research areas than the analytical modeling allows to do; no restrictions on displaying the dependencies between the parameters (contours) of the model;
- the ability to evaluate the system functioning not only in statics, but also in the process of implementing these same processes;

- possibility of obtaining a considerable amount of data about the studied object (random values distribution law, numerical values absolute and relative);

- the most accurate and rational reflection of the "result-cost" process in comparison with analytical and physical modeling.

However, along with the advantages the simulation modeling of economic processes has a variety of disadvantages:

- model development requires a lot of time and a large amount of data for true imitation, which does not always justify the result;

- the assessment of the model accuracy, its adequacy from the economic point of view of the studied processes is rather difficult;

- high requirements to the experts involved in simulation modeling, since in addition to mathematical calculations, knowledge of economic laws is required in order to be able to adequately evaluate and interpret model calculations;

- community of application and individuality of implementation of each model, taking into account the processes under which the modeling is carried out.

Based on the simulation model development at the job market, it is possible to determine the information support and monitoring system of the job market, to identify different parameters of the job market; to forecast on the basis of calculated data the job market development, to determine the most influential factors on the demand and supply changes at the job market, to develop measures to improve the situation on the job market on the basis of the relevant parameters forecast of the economic system development, thereby increasing the employment level. Demographic and migration factors are also important while influencing the employment rate of the population. On the basis of simulation modeling, it is possible to forecast these parameters in order 
to implement the necessary measures for the labor market development in Ukraine (Kolot, 2010). For the application of simulation modeling, it is advisable to apply a system dynamics method, which is used to study the behavior of complex systems over time, depending on the influence and structure of system elements and the interaction between them. These include causal relationships, feedback circuit, reaction latency, environmental impact etc. In fact, simulation models are the simulators for the development and implementation of management decisions through a situational, alternative approach to the study of trends in the development of the studied objects.

In order to apply simulation modeling of the processes of influence on the population employment, it is necessary to determine the causal relationships between the system indices; conducting experiments with models at different values of the input parameters; selection of parameters for impact analysis; analysis of the sensitivity and strength of the impact of each factor on the resultant index; the possibility of the interrelated models system development detailing the impact factors for individual indices of other models, etc. (Emelyanov, 2002). Simulation modeling of factors influencing the employment of the population includes:

- modeling of the relationships between indices and exploring the factor interaction within the employment system;

- modeling of ways of indices integration and research of their influence on the possibility of a job seeker employment;

- setting values and the nature of the variable model input parameters (impact factors);

- identifying more important indices for the employment of population;

- conducting experiments with a model for forecasting the result, based on the control and change of one of the parameters;

- using a simulation model to improve the employment support system.
A number of factors have been used to develop the model, which influence the formation and development of the job market in the country, and regulate labor supply and demand in the long run. In previous works, the degree of each factor impact was determined on the basis of correlation-regression analysis, as a result of which they were grouped on the direct-acting loops and the reverse-acting loops.

The degree of each factor impact was determined based on the use of correlation-regression models. In general, the regression model looks like this:

$$
Y=f(X)
$$

where $Y$ - dependant variable;

$X$ - independent variable (impact factor).

On the basis of such analysis, the main impact factors on the population employment were identified and the force of influence of each factor was highlighted.

It is necessary to consider the value of the determination coefficient $\left(\mathrm{R}^{2}\right)$, the model with a constant takes the value from 0 to 1 . The coefficient characterizes the dependence of the dependent variable on the factors of impact. When evaluating the regression models, this is interpreted as being consistent with the data model. For acceptable models, it is assumed that the determination coefficient should be at least $50 \%$ (in this case, the multiple correlation coefficient exceeds $70 \%$ to modulo). Models with a determination coefficient above $80 \%$ can be considered quite significant (correlation coefficient exceeds 90\%). The value of the determination coefficient 1 indicates a functional dependence between the variables (Korobova, 2006). Therefore, in the simulation model, the parameters were chosen, the determination coefficient being $>0.5$. Thereby, the most influential factors were selected.

Having analyzed the methodological support of the process of employment of the 
population, by means of simulation modeling it would be expedient to determine the interrelation of factors of impact on the process of employment of the population at the expense of interaction of universities and business, which will allow to develop organizational support of the state regulation of employment (Fig. 1).

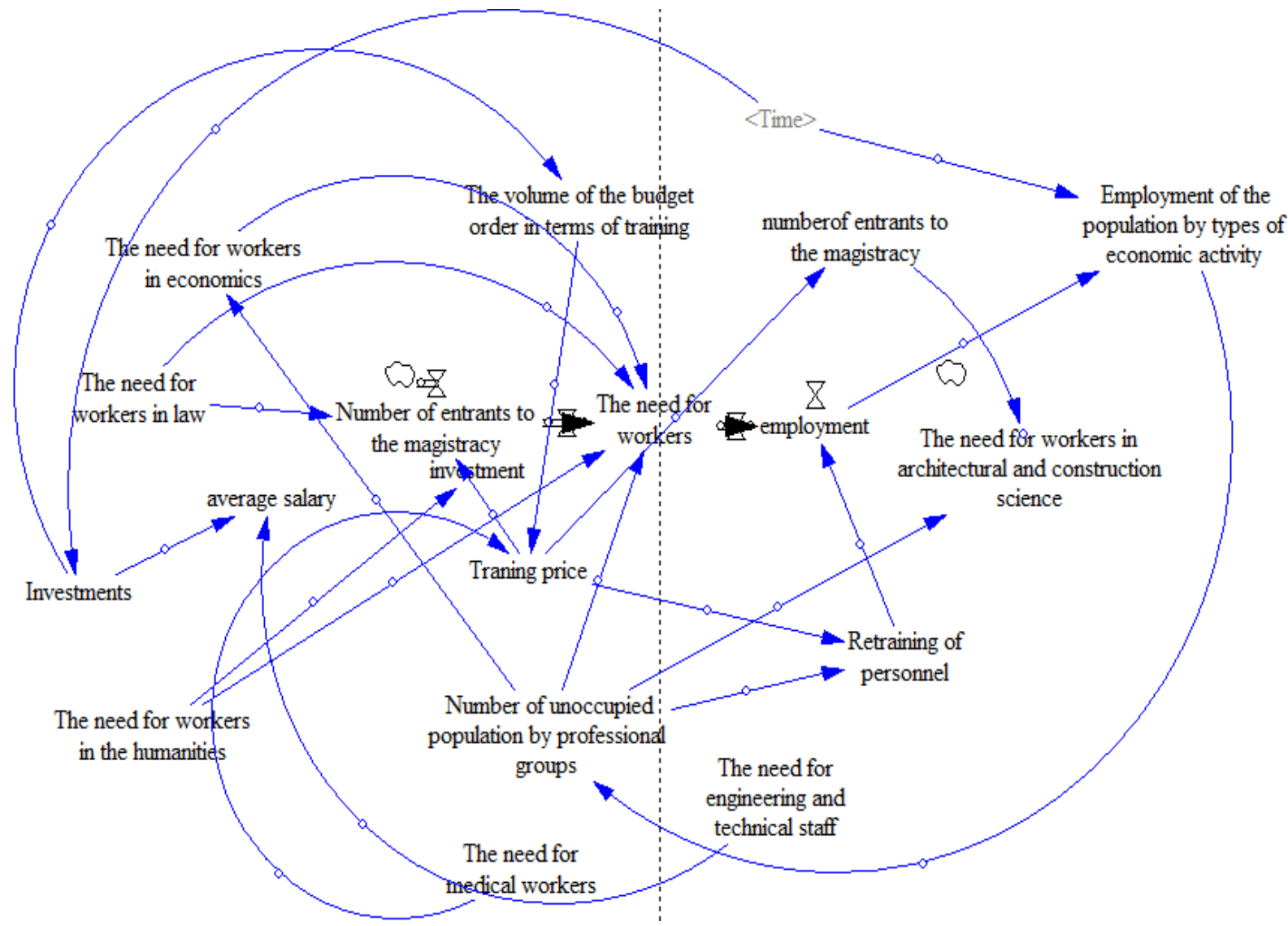

Fig. 1. Model of cross-influence of external factors on the population employment level

The system of equations of the employment model includes the following ratios: the main variables are:

Employment of the population by types of economic activity $=$ Number of unoccupied population by professional groups / The need for workers;

Retraining of personnel $=33681 *$ Training price Number of entrants to the magistracy; $\left(\mathrm{R}^{2}=0.89\right)$;

Number of entrants to the magistracy $=$ $=0.08 *$ Training price $+0.62 *$ The volume of the budget order in terms of training +16.2 $\left(\mathrm{R}^{2}=0.91\right)$;

Employment of the population by types of economic activity $=0,11+$ Investments $*$ average salary $+0.23\left(\mathrm{R}^{2}=0.83\right)$;
Employment of the population by types of economic activity $=52.3^{*}$ Retraining of personnel $+0.615^{*}$ The need for workers in law + + The need for workers in economics + The need for workers in the humanities + The need for medical workers + The need for engineering and technical staff + The need for workers in architectural and construction science + + The need for civil servants $\left(\mathrm{R}^{2}=0.87\right)$.

By virtue of the determined mathematical calculations, only those parameters that have a weight influence on the employment of population over 0.5 were selected, which on the basis of the correlation-regression analysis use characterize the degree of influence of one or another factor. Those parameters which power of influence is less than 0.5 were not considered in the model. 
The model shows that the employment process is influenced by a number of factors, such as: training price, number of entrants to the magistracy, average salary, the need for workers, number of unoccupied population by professional groups), the volume of the budget order in terms of training, investments, personnel retraining, employment of the population by activity.

However, one of the main problems is the dissonance between training costs, qualifications and wages. Low wages, especially for recent graduates, encourage them to find work abroad. Therefore, one of the directions of state regulation of employment and preservation of the labor potential of the state is to provide such conditions under which the specialists will be employed in the country.

Among the strategic directions for regulating Ukraine's economy is to follow the experience of those countries that have achieved greater success in economic development. In order to bring the country to the international market, emphasis should be placed on promoting the introduction of "high technology", creation of new technology, innovative programs, scientific and technological research, which in turn requires the potential for social development, a system of powerful higher education and a skilled workforce. Only those countries that provide an upgrade of the education system, meet the needs of the post-industrial society in the field of qualifications, ensure the availability of higher education for a wide range of people, are able to adapt to the requirements of modern scientific and technological progress. Each country has its own specificity in regulating the interaction between labor markets and educational services. Foreign experience proves that the developed countries have been able to successfully integrate science, education and business, in particular through the development of university complexes, network structures, etc., and have achieved greater success than Ukraine.
Effective interaction of education, science and business in our country is also not established, which negatively affects the innovative development of the economy and can be solved by borrowing the experience of foreign countries in regulating the systems of labor and education of foreign countries, and used in the economic mechanism of interaction of labor markets and educational services.

Elements of such regulation include the system of hiring and retraining of employees, training and promotion of education accessibility (raising requirements for secondary education, development and implementation of education crediting, grants, charitable assistance system etc.). From these areas of influence on the interaction of the system of work and education, the Japanese experience deserves attention. Japanese employers are acting out of the ordinary way for our country: first, they hire people, then analyze their abilities and make decisions about their use, perceiving the workforce as the "uncut stones" from which they can build a "wall, connecting them to each other in the best way, taking into account their shape, age, and expected changes". In case of change of a Japanese enterprise activity, its employees are retrained, mostly at their own request. Competition that exists in the education system and in social life is very important in society. It is necessary to struggle even for secondary education, and for entering the university the Japanese have been preparing almost since childhood. The idea of keeping outdated jobs in the modern era makes no sense. The value of using the simulation of different processes is that it is based on the principle of system analysis, which allows the study of the analyzed system on the basis of operational analysis, which includes the following stages: target setting, conceptual model development, simulation model development and implementation, verification of accuracy and model adequacy, estimation of the results and forecasts accuracy, planning and 
forecasting of events, decision making. This approach allows the use of simulation modeling as one of the methods of decision making under uncertainty using the principles of the systematic approach. Based on the study on the characteristics of changes in employment in the context of social and economic crisis and current trends in the employment market in Ukraine, we can identify the main directions of organizational measures to regulate the labor market (Libanova, 2003):

- formation of comprehensive legislative, regulatory, organizational and information support through interaction of the state, business and universities in the sphere of supply and demand balance in the labor market;

- reforming the employment service in accordance with the provisions of the state employment service and the rules of operation of employment centers to meet the needs of clients;

- modernization of the mechanism of social services provision in the field of vocational guidance.

The main means of the proposed measures implementation include: investments and subsidies; composite demand; salary; unemployment benefits; taxes and privileges on taxation; credit and monetary instruments (central bank discount rate, preferential loans); economic sanctions (fines). As the experience of advanced economies shows, increasing investment in human resources is one of the conditions for the production systems modernization. Today it is urgent to improve the legislative, regulatory and legal mechanism of state regulation of employment, which requires updating the legislation in the field of social and labor relations, elimination of gaps and legal conflicts in labor law, creation of proper conditions for exercising public supervision, depriving employers of the opportunity to use illegal labor, strengthening and applying penalties for violation of labor law requirements, creating the necessary conditions for bringing the sphere of social and labor relations from the cold etc.

\section{Conclusions.}

Thus, simulation of economic processes is mainly used to manage complex business processes, when conducting experiments with discrete-continuous models of complex economic objects to obtain and study their dynamics in risk situations.

The process of simulation of factors influencing the population employment in Ukraine showed that the main factors influencing this process are the economic, educational and professional factors. As the dynamics and change of economic processes under the influence of innovative development of the economy lead to the changes in the requirements for educational qualification level of specialists, new professions that need new knowledge and skills are emerging. The vocational education system is slowly responding to such challenges, as the country lacks a system for forecasting labor market needs in the medium and long term outlook. The old-fashioned training standards lead to the increase in the supply and demand imbalance in the labor market, and the employment level reduction. This situation requires state regulation at the level of the education system, cooperation between universities and business, in order to create an effective mechanism for ensuring the development of employment in the country.

\section{References}

Bobilev, V. E (2012), “Approach to creation of systems of automated assessment of knowledge using modern information technologies", Bulletin of the National University of Defense of Ukraine, vol. 4, pp. 11-16.

Dorokhov, O. V. (2008), "Basics of fuzzy modeling of the influence of environmental factors on the functioning of enterprises”, Proceedings of Kharkiv University of the Air Force, vol. 2, pp. 124-127.

Emelyanov, A. A. (2002), Imitasionnoe modelirovanie economicheskih procecov [Simulation modeling of economic processes], Finance and Statistics, Moscow, Russia, 368 p. 
Heyets, V. M, Klebanova, T. S, Chernyak, O. I. and Kyzym, M. O (2008), Modeli i metody socialno-ekonomichnogo prognozuvaniya [Models and methods of socio-economic forecasting], VD INZHEK, Kharkiv, Ukraine, $396 \mathrm{p}$.

International Labour Organization (1988), Convention "On employment promotion and protection against unemployment”, No. 168, available at: https://zakon.rada.gov.ua/laws/show/993 182 (Accessed 22 April 2019).

Kizim, N. A, Haustova, V. E, Polyakova, O. Y. and Omarov, S. H (2010), Modelirovanie ustoichevogo razvitiya regionov [Modeling of sustainable development of regions], ID INZHEK, Kharkiv, Ukraine, $180 \mathrm{p}$.

Kolot, A. M (2010), Socialno-trudova sfera: stan vidnosyn, novi vyklyky, tendencii rozvytku [Social and labor sphere: the state of relations, new challenges, tendencies of development], KNEU, Kyiv, Ukraine, $251 \mathrm{p}$.

Korobova, M. V. (2006), Osnovy matematychnogo modeluvannia economichnyh, ecolohichnyh ta socialhyh procesiv [Fundamentals of mathematical modeling of economic, environmental and social processes], Bogdan Educational Book, Ternopil, Ukraine, 304 p.

Kravets, I. O. (2010), Imitatsiine modeliuvannia [Simulation modeling], Vydavnytstvo ChDU im. Petra Mohyly, Mykolaiv, Ukraine, $108 \mathrm{p}$.

Libanova, E. M. (2003), Rynok pratsi [Labor market], Center for Educational Literature, Kyiv, Ukraine, 224 p.

Tomashevskyi, V. M. (2005), Modeliuvannia system [Systems modeling], Vydavnycha hrupa BHV, Kyiv, Ukraine, $352 \mathrm{p}$.

Цей твір ліцензовано на умовах Ліцензії Creative Commons «/з Зазначенням Авторства = Некомериійна 4.0 Міжнародна» (CC BY-NC 4.0). This is an open access journal and all published articles are licensed under a Creative Commons "Attribution-NonCommercial 4.0 International" (CC BY-NC 4.0). 